\title{
A súlyos korai gyermekkori fogszuvasodás előfordulása és összefüggései pécsi bölcsődések között
}

\author{
Radácsi Andrea dr. ${ }^{1}$ - Dergez Tímea dr. ${ }^{2}$ - Csabai Laura dr. ${ }^{1}$ \\ Stáczer Nóra dr. ${ }^{1}$ - Katona Krisztián dr. ${ }^{1}$ \\ Balásné Szántó Ildikó dr. ${ }^{1}$. Sándor Balázs dr. ${ }^{1}$

\begin{abstract}
${ }^{1}$ Pécsi Tudományegyetem, Klinikai Központ, Fogászati és Szájsebészeti Klinika, Gyermekfogászati Részleg, Pécs ${ }^{2}$ Pécsi Tudományegyetem, Általános Orvostudományi Kar, Bioanalitikai Intézet, Pécs
\end{abstract}

\begin{abstract}
Bevezetés és céllitüzés: A 3 év alatti korcsoportban a súlyos kisgyermekkori fogszuvasodás (S-ECC) gyakoriságának vizsgálata és a kisgyermekes szülők szájegészséggel kapcsolatos ismereteinek felmérése.

Módszer: Háromszázhatvankét, 36 hónapos vagy annál fiatalabb gyermek (átlagéletkor: 28,49 \pm 5,25 hónap) fogászati szưrővizsgálatát végeztük el, és szüleik számára önkéntesen kitölthető kérdőívet állítottunk össze. A 306 kitöltött kérdőív eredményét a gyermekek fogászati statusával egyénenként összevetve statisztikai analízist végeztünk.

Eredmények: A gyermekek fogászati szúrésekor $15,46 \%$ volt a cariesprevalencia: df-t-index =0,685 $\pm 2,20$; az általunk javasolt, az előtört fogak számával módosított df-t-index $=0,758 \pm 2,42, \mathrm{SiC}$-index $=2,06 \pm 3,33$. A vizsgált populációban nem találtunk tömött vagy fogszuvasodás miatt eltávolított fogat. A korábban szájhigiénés tájékoztatásban részesült/nem részesült szülők gyermekeinél nem volt szignifikáns különbség a szuvas fogak számának $(\mathrm{p}=0,196)$, a fogyasztott folyadék cukortartalmának $(81,5 \% / 71,5 \%)$ és a bevitel módjának $(\mathrm{p}=0,453)$ tekintetében. A gyermeküket 6 hónapos korukig kizárólagosan anyatejjel tápláló édesanyák nagyobb eséllyel választották a vízzel történő itatást $(75 \% / 52 \%)$ pohárból $(68,1 \% / 28,8 \%)$ a későbbiekben. Az édesanya legmagasabb iskolai végzettsége kulcsszerepet játszik mind az anyatejes táplálás melletti elhivatottságban (felsőfok: 53,4\%, középfok: 34,2\%, alapfok: 37,5\%), mind a cariesfrekvencia csökkentésében $(\mathrm{p}=0,015)$.

Következtetés: A szülői szájhigiénés prevenciós tájékoztatás jelenleg nem hatékony. Eredményeink alapján a fogászati szürést 1 éves kor előtt meg kell kezdeni, amely a hatékony, rendszeres fogászati prevenciós tanácsadás lehetőségét is megteremtené. Szükségesnek látjuk a védőnők és a gyermekháziorvosok folyamatos továbbképzésében a kisgyermekkori fogszuvasodás alapismereteinek integrációját.
\end{abstract}

Orv Hetil. 2021 ; 162(22): 861-869.

Kulcsszavak: ECC, kisgyermekkori fogszuvasodás, bölcsődéskorúak fogászati szưrése, szülői tájékozottság, táplálási szokások

\section{Prevalence and correlation of severe early childhood caries among preschool children in Pécs}

Introduction and objective: To investigate the frequency of severe early childhood caries (S-ECC) under 3 years of age and to assess the oral health related knowledge of parents/guardians with preschool children.

Method: 362 children younger than 36 months (mean age: $28.49 \pm 5.25$ months) were screened and a voluntary questionnaire for their parents was compiled. Statistical analysis was carried out comparing the results of the 306 completed questionnaires with the dental status of the screened children.

Results: Caries prevalence in the examined population was $15.46 \%$, df-t index $=0.685 \pm 2.20$, our suggested modified $\mathrm{df}-\mathrm{t}$ index based on the number of erupted teeth $=0.758 \pm 2.42, \mathrm{SiC}$-index $=2.06 \pm 3.33$. No filled or extracted tooth due to caries was found in the study group. There was no significant difference in the number of carious teeth $(\mathrm{p}=0.196)$, consumption of sugar-containing drinks $(81.5 \% / 71.5 \%)$ and administration of drinks $(\mathrm{p}=0.453)$ in the case of children whose parents had previously received/not received oral hygiene information. Mothers who exclusively breastfed until the age of 6 months were more likely to choose to offer water $(75 \% / 52 \%)$ from cup $(68.1 \% / 28.8 \%)$ 
later. The mother's highest level of education plays a key role in both the commitment to breastfeeding (tertiary: $53.4 \%$, secondary: $34.2 \%$, primary: $37.5 \%)$ and in reducing the incidence of caries $(\mathrm{p}=0.015)$.

Conclusion: Parental oral hygiene preventive instruction is currently ineffective. Based on our results, dental screening should be started before the age of 1 year, that would also provide an opportunity of effective, regular dental prevention counseling. There is a need for the integration of the basics of early childhood caries in the continuous professional training of district nurses and pediatricians.

Keywords: ECC, early childhood caries, dental screening of preschool children, parental dental knowledge, dietary habits

Radácsi A, Dergez T, Csabai L, Stáczer N, Katona K, Balásné Szántó I, Sándor B. [Prevalence and correlation of severe early childhood caries among preschool children in Pécs]. Orv Hetil. 2021; 162(22): 861-869.

(Beérkezett: 2020. szeptember 2.; elfogadva: 2020. október 19.)

\section{Rövidítések}

$\mathrm{CI}=($ Care Index $)$ ellátási index $;$ def $=($ decayed, extracted, filled) szuvas, eltávolított, tömött (fog tejfogazatban); df = (decayed, filled) szuvas, tömött (fog tejfogazatban); dmf $=($ decayed, missing, filled) szuvas, hiányzó, tömött (fog tejfogazatban); DMF-T = (decayed, missing, filled teeth) szuvas, hiányzó, tömött fogak (felszíntól függetlenül, a maradó fogazatban; a szuvasodásban megbetegedett fogak számát jelöli); ECC $=($ early childhood caries) kisgyermekkori fogszuvasodás; HBCs = homogén betegségcsoportok; ICCMS = (International Caries Classification and Management System) Nemzetközi Caries Osztályozási és Ellátási Rendszer; ${ }^{\mathrm{m}} \mathrm{df}=$ módosított df; S-ECC = (severe early childhood caries) súlyos kisgyermekkori fogszuvasodás; $\mathrm{SiC}$ index $=$ Significant Caries index; $\mathrm{WHO}=($ World Health Organization) Egészségügyi Világszervezet

A kisgyermekkori fogszuvasodás (early childhood caries, röviden: ECC) is súlyos egészségügyi problémát jelent mind a fejlődő, mind a fejlett országokban [1]. Az ECC megelőzhető, de napjainkban is több mint 600 millió gyermek érintett világszerte, és túlnyomó részük ellátatlan marad [2]. A 72 hónapnál, azaz 6 évesnél fiatalabb gyermekek esetében, ha caries jelenléte igazolható a tej-

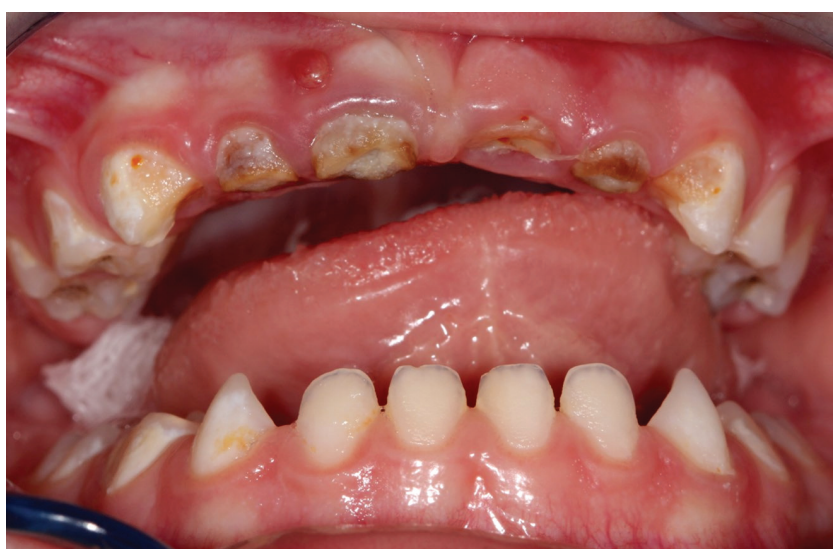

1. ábra $\quad$ A korai gyermekkori fogszuvasodás klinikai képe 3 éves páciensen (saját fotódokumentációból) fogazatban (beleértve a tömött, illetve a caries következményeként eltávolításra került tejfogakat is), kisgyermekkori fogszuvasodásról beszélünk (1. ábra). A 3 éves kor alatti gyermekeknél kialakult fogszuvasodást a szakirodalom súlyos kisgyermekkori fogszuvasodásként (severe early childhood caries, röviden S-ECC) írja le [3]. S-ECC-ként definiáljuk továbbá, ha 3 és 6 éves kor között egy felső tejfrontfog szuvas, tömött, vagy caries következményeként hiányzik, illetve ha a dmf-szám 4 éves korig négynél, 5 éves korig ötnél magasabb (1. táblázat) [4]. Az ECC etiológiájában és progressziójában kiemelkedő szerepet játszik a finomított szénhidrátokat tartalmazó étrend. Megkülönböztetünk I. (enyhe-közepes), II. (közepes-súlyos) és III. (súlyos) típust. Az I. típusú ECC metsző- vagy molaris fog felszínén jelentkező izolált szuvasodás, melyet félkemény, kemény táplálék és rossz szájhigiéné okoz. A II. típusú ECC esetén a felső metszők érintettek, emellett a molaris fogak buccalis felszínén is lehet caries, de az alsó metszők a nyál védőhatása miatt tipikusan egészségesek. A fó etiológiai faktor ebben az esetben cukros folyadék itatása cumisüvegból vagy a gyermek igénye szerinti szoptatás akár jó szájhigi-

1. táblázat A korai gyermekkori fogszuvasodás (early childhood caries ECC) és a súlyos korai gyermekkori fogszuvasodás (severe early childhood caries - S-ECC) klasszifikációja [4]

\begin{tabular}{lll}
\hline $\begin{array}{l}\text { A gyermek } \\
\text { kora (hónap) }\end{array}$ & ECC & S-ECC \\
\hline$<12$ & & 1 vagy több dmf-s \\
$12-23$ & 1 vagy több dmf-s \\
$24-35$ & 1 vagy több dmf-s \\
$36-47$ & 1 vagy több dmf-s & $\begin{array}{l}1 \text { vagy több szuvas, tömött } \\
\text { vagy caries miatt hiányzó } \\
\text { felső tejfrontfog vagy } \\
\text { dmf-s-érték }>4\end{array}$ \\
& & 1 vagy több szuvas, tömött \\
& & $\begin{array}{l}\text { vagy caries miatt hiányzó } \\
\text { felső tejfrontfog vagy } \\
\text { dmf-s-érték }>5\end{array}$ \\
\hline
\end{tabular}

dmf-s = szuvas, hiányzó, tömött (fog) - felszín 
éné mellett. A III. típus esetén szinte minden tejfog érintetté válhat cariogen étrend és rossz szájhigiéné talaján $[4,5]$. A szocioökonómiai, genetikai és szájhigiénés háttér mellett [6] nagyban meghatározó tényező továbbá a szülők/gondviselők ismerete vagy annak hiánya a cariespreventív diétáról [7]. A szülők oktatása, felkészítése gyermekeik szájegészségének megőrzésére az egészségügyi szakemberek - beleértve a gyermekorvosok, a védőnők és a várandósság során a fogászati szűróvizsgálatot végző fogorvosok - felelőssége lenne. A jelenleg érvényben lévő magyarországi szabályok szerint (26/1997. [IX. 3.] NM rendelet az iskola-egészségügyi ellátásról) a gyermekek rendszeres fogászati szürővizsgálatára 3 éves kortól kerül sor, a gyermek által látogatott nevelési-oktatási intézmény szervezésének keretein belül. Tehát a gyermekek életük első 3 évében „láthatatlanok” a fogászati ellátórendszer számára, nem valósulhat meg a száj és a fogazat egészségét támogató fogorvos-szülő kommunikáció, valamint sok esetben a már ekkor megjelenő kóros elváltozások korai felismerése és kezelése.

Az Amerikai Gyermekfogorvosok Társasága hangsúlyozza a nagyon korai prevenció fontosságát és a gyermek individuális igényeinek megfelelő folyamatos fogászati gondozást. A társaság ajánlása szerint, hazánkkal ellentétben, a kisgyermek első fogászati vizsgálatát javasolt az első előtörő tejfog és a gyermek első születésnapja közötti időintervallumban elvégezni [8].

A fogászati kezelés, a szuvas fogak ellátása kisgyermekkorban, de különösen 3 éves kor alatt rendkívül időigényes és nehezen kivitelezhető. A definitív ellátás vagy egyáltalán bármilyen ellátás elvégzése ambuláns körülmények között sok esetben nem lehetséges, ezért a kezelések egy része csak általános anesztéziában végezhető el [9]. A mentálisan sérült páciensek fogászati kezelésének általános anesztéziában történő elvégzésére hazánkban is van lehetőség [10], azonban egészséges, nem speciális ellátást igénylő páciensek részére ez az alternatíva - számos európiai országgal ellentétben - a társadalombiztosítás terhére nem mindenki számára érhető el. Ez még inkább szükségessé teszi a korai prevenció hatékony megvalósítását. A Pécsi Tudományegyetem Klinikai Központja Fogászati és Szájsebészeti Klinikájának Gyermekfogászati Osztályán 2014 áprilisa óta rendszeresen végezzük ezen páciensek teljes körü, fogmegtartásra törekvő, altatásban történő ellátását (egynapos sebészeti ellátás körében, homogén betegségcsoportokhoz [HBCs] rendelt súlyszám alapján társadalombiztosítás révén finanszírozva [100C: Általános anesztéziában végzett fogászati ellátás]) és hosszú távú gondozását.

Irodalomkutatásunk során nem volt fellelhető magyarországi adat a 3 évesnél fiatalabb gyermekek cariesprevalenciáját illetően. Kutatásunk elsődleges célja volt, hogy felmérjük a pécsi bölcsődés, 3 évnél fiatalabb gyermekek fogászati állapotát. Azért ezt a csoportot választottuk, mert hazánkban csak 3 éves kortól kötelező az óvodalátogatás, ezáltal a hathavonta történő fogászati szưrővizsgálat is. Így ebből a rendszerből a 3 év alattiak kimaradnak.

A kisgyermekkori fogszuvasodás megelőzésében elengedhetetlen a tájékoztatás, a kórkép ismertetése a szülők/gondozók számára egészségügyi szakemberek által (fogorvos, fogászati szakasszisztens stb.). A megelőzés fontos eleme a cukorfogyasztás csökkentése. Paglia és mtsai (2016) vizsgálata kimutatta, hogy kisgyermekkorban a táplálkozás a fó cariologiai faktor, ezen belül is a finomított szénhidrát fogyasztása és annak beviteli módja [11]. Vizsgálatunk második részében ezért önkéntesen kitölthető kérdőív segítségével azt vizsgáltuk, hogy kaptak-e tájékoztatást a szülők a gyermek szájegészségével kapcsolatban egészségügyi szakembertől, illetve ez milyen módon befolyásolta a gyermek szájhigiénés szokásait, táplálását és a caries frekvenciáját.

Tanulmányunkkal szeretnénk felhívni a figyelmet a hazánkban jelenleg múködő gyermekfogászati szűrőrendszer átalakításának, kiterjesztésének szükségességére, hogy lehetőségünk nyíljon korai prevenciós konzultációra, illetve a magas caries-rizikócsoportba tartozó gyermekek mielőbbi felderítésére és gondozására.

\section{Résztvevők és módszerek}

\section{Szürôpizsgálat}

Pécs Megyei Jogú Város Önkormányzatának a Kisgyermek Szociális Intézmények által fenntartott minden bölcsődéjében és a Pécsi Tudományegyetem Általános Orvostudományi Kara által üzemeltetett bölcsődében végeztük el a kisgyermekek fogászati szűrővizsgálatát 2019-ben. A felkért intézmények egyike sem utasította el a szürővizsgálatban való részvételt. A vizsgálat előtt a szülők/gondviselők írásban kitöltötték a beleegyező nyilatkozatot, mellyel hozzájárultak gyermekeik szürővizsgálatának elvégzéséhez és a kérdőív kitöltéséhez. A bölcsődék csak a beleegyezésüket adó szülők gyermekeinek adatait bocsátották rendelkezésünkre. A szürést visszautasítók arányáról nincs adatunk. Az adatok feldolgozását és statisztikai összesítésüket a Pécsi Tudományegyetem Etikai Bizottságának engedélyével (engedélyszám: PTE/75208/2018) végeztük el. Bár a vizsgálatot minden kisgyermeken elvégeztük, a tanulmányban csak a 36 hónapos vagy annál fiatalabb gyermekek adatait értékeltük. Vizsgálatunkban háromszázhatvankét, 36 hónapos vagy annál fiatalabb gyermek (176 fiú, 186 lány, átlagéletkor: $28,49 \pm 5,52$ hónap) fogászati szűrővizsgálata valósult meg.

A gyermekek szűrését az alábbi protokoll alapján kiviteleztük:

- A szűrést a bölcsődében végeztük előzetes időpontegyeztetést követően.

- A szűrést lehetőség szerint reggeli előtt végeztük, a gyermekek otthoni fogápolását követően. 
- A fényforrást fejlámpákkal biztosítottuk, és a vizsgálathoz egyszer használatos fogászati tükröket használtunk.

- A vizsgálatot két fogorvos végezte, az eredményeket statuslapon fogászati szakasszisztensek kézzel rögzítették. A fogakat a standardizált, nemzetközileg elfogadott International Caries Classification and Management System (ICCMS - Nemzetközi Caries Osztályozási és Ellátási Rendszer) szerint értékeltük (2. ábra). A vizsgálat megbízhatósága érdekében a fogorvosok az ICCMS e-learning online képzés önértékelő tesztjének elvégzését követően mérték fel a gyermekek fogászati állapotát (https://www.iccmsweb.com/) $[12,13]$. A fogakat szuvasnak tekintettük, ha 3-as vagy annál magasabb értékü elváltozást diagnosztizáltunk. Az ICCMS szerinti l-es vagy 2-es érték, vagyis incipiens (reverzibilis) caries rögzítése a vizsgálat körülményeit figyelembe véve félrevezető

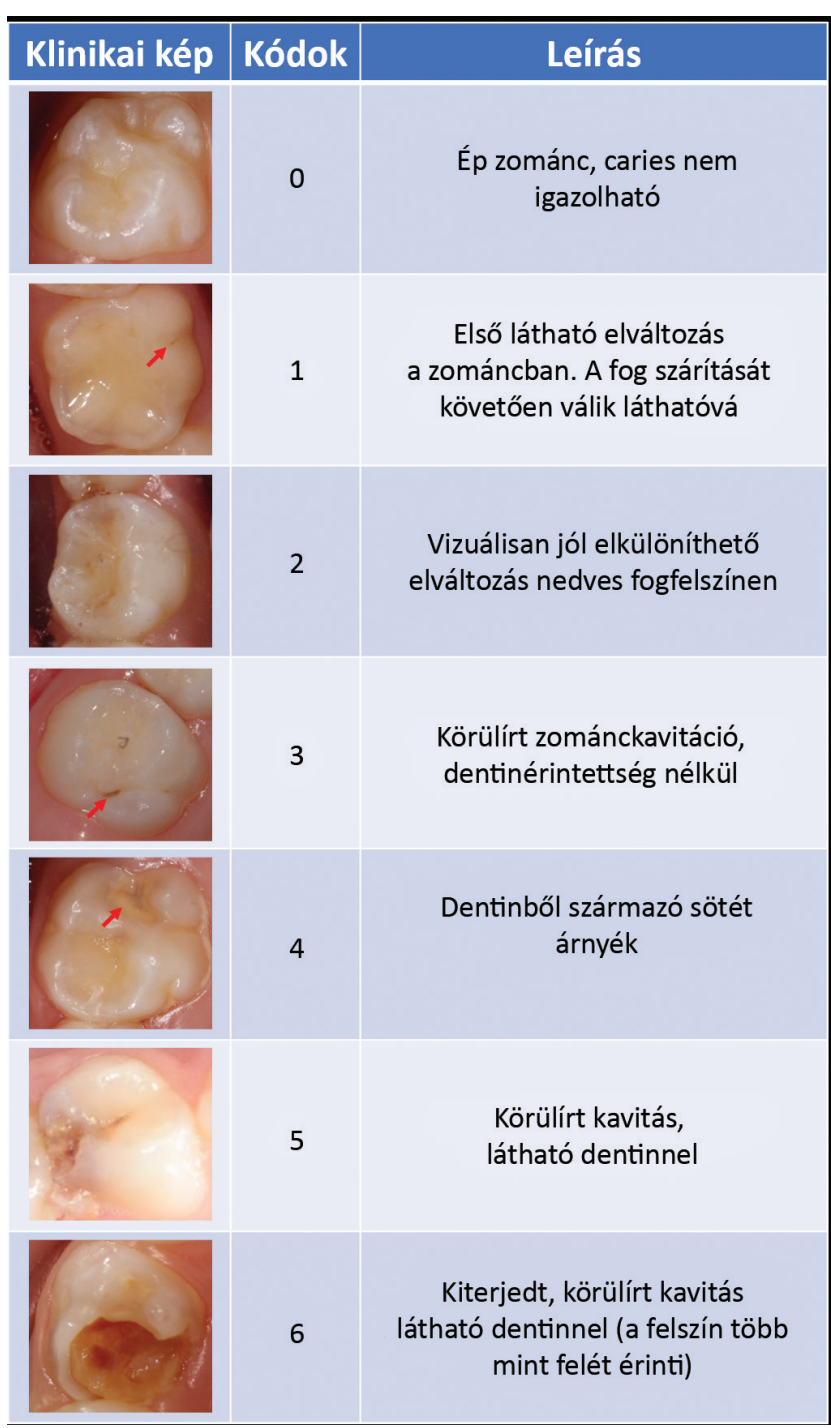

2. ábra

Az ICCMS (International Caries Classification and Management System - Nemzetközi Caries Osztályozási és Ellátási Rendszer) diagnosztikai fokozatai klinikai képekkel szemléltetve (saját fotódokumentációból) lett volna. Jelen vizsgálatunkban az ICCMS szerinti 3-6-os értékeket nem különítettük el egymástól, mivel ezen esetekben fogászati ellátás már indokolt lenne.

- A vizsgálat eredményeit egyénenként, névre szólóan kitöltött formanyomtatványon összegeztük, melyet az óvónők és gondozók továbbítottak a szülők felé.

A def-index (decayed [szuvas], extracted [caries miatt eltávolított], filled [tömött]) egy adott egyén szuvas, eltávolított és tömött tejfogainak számát jelenti, míg a defindex összegét a vizsgált populáció létszámával elosztva egy csoport tejfogazati statusát reprezentáló indexet kapunk. Mivel a hiányzó tejfog fiziológiás vagy patológiás eredete nem mindig igazolható, sok esetben df-indexszel jellemezzük a vizsgált csoport cariesérintettségét. A df-t (tooth) a fogak, a df-s (surface) a fogfelszínek szuvasodására utal. Az index számítása a df-szám (a szuvas és tömött fogak száma egyénenként) és a vizsgált egyének számának hányadosaként definiálható.

A df-t-index a teljesen elötört tejfogazatra értelmezendő epidemiológiai fogalom, azonban az általunk vizsgált életkorú gyermekek tekintetében esetenként még részlegesen előtört tejfogazatot találtunk. Véleményünk szerint az általunk javasolt módosított df-t ( $\left.{ }^{\mathrm{m}} \mathrm{df}\right)$-index, amely figyelembe veszi a már áttört tejfogak számát, pontosabb képet ad az adott egyén cariesérintettségéról:

${ }^{m}$ df-index $=$ df $\times 20$ (teljesen áttört tejfogazat fogszáma) / a vizsgált fogak száma, egyénenként

${ }^{\mathrm{m}} \mathrm{df}$-index $=\mathrm{df} \times 20$ / a vizsgált fogak száma / a vizsgált gyermekek száma, a vizsgált populációra

(Például 2 szuvas tejfog esetén a teljes előtört tejfogazatban: df-index $=2 ; 2$ szuvas tejfog 16 áttört tejfog esetén: ${ }^{\mathrm{m}} \mathrm{df}$-index $=2 \times 20 / 16=2,5$.)

A mdf-index húen tükrözi a helyzet súlyosságát nem teljesen előtört tejfogazat esetén.

A df- és a ${ }^{\mathrm{m}} \mathrm{df}$-indexen kívül vizsgálatunk során a szignifikáns fogszuvasodás index (Significant Caries Index, röviden: SiC) és az ellátási index (Care Index, röviden: CI) értékeit is kalkuláltuk. A SiC-index a vizsgált populáció legrosszabb df-értékkel rendelkező egyharmadát jellemzi. A vizsgált személyek df-indexét az értékeknek megfelelően növekvő sorrendbe állítják, és a legmagasabb értékkel rendelkező egyharmad átlag-df-indexét kalkulálják [14]. A CI a restaurált fogak arányát értékeli, a tömött fogak száma és a dmf-index hányadosaként kalkulálható: $\mathrm{CI}=$ tömött $/ \mathrm{dmf} \times 100(\%)$ [15].

\section{Szülöi kérdöív}

A kérdőívet 306 szülő töltötte ki és küldte vissza értékelésre (56 szülő [15,46\%] beleegyezett a szűrővizsgálatba, de nem küldte vissza a kérdőívet). A szürésben részt vevő gyermekek szülei számára készített kérdőív az alábbiakat tartalmazta (2. táblázat):

- A szülők legmagasabb iskolai végzettsége.

- A fogmosás fontossága.

- A kisgyermek táplálása 6 hónapos korig. 
2. táblázat $\mid$ Szülői kérdőív ( *a kitöltés hiányossága miatt nem került kiértékelésre)

\begin{tabular}{|c|c|c|}
\hline & \multicolumn{2}{|l|}{ Személyes adatok } \\
\hline & \multicolumn{2}{|c|}{ Nem, születési dátum, születési hét } \\
\hline & Kérdések & Válaszlehetőségek \\
\hline \multirow[t]{3}{*}{ Táplálás } & Táplálás féléves korig & $\begin{array}{l}\text { Anyatej, tápszer, } \\
\text { anyatej-tápszer }\end{array}$ \\
\hline & $\begin{array}{l}\text { Italfogyasztás (több válasz } \\
\text { is megjelölhető) }\end{array}$ & $\begin{array}{l}\text { Víz, tea cukor nélkül, } \\
\text { tea cukorral, egyéb: }\end{array}$ \\
\hline & Az italfogyasztás formája & $\begin{array}{l}\text { Cumisüveg, pohár, } \\
\text { egyéb: }\end{array}$ \\
\hline \multirow[t]{6}{*}{ Tájékoztatás } & $\begin{array}{l}\text { Kapott-e korábban } \\
\text { bármilyen információt } \\
\text { gyermeke szájegészségével } \\
\text { kapcsolatban? }\end{array}$ & Igen, nem \\
\hline & $\begin{array}{l}\text { Ha az előző válasz „igen”, } \\
\text { kitől?* }\end{array}$ & $\begin{array}{l}\text { Fogorvos, gyermek- } \\
\text { orvos, védőnő, egyéb: }\end{array}$ \\
\hline & Milyen információt kapott? & (Szöveges válasz) \\
\hline & $\begin{array}{l}\text { Terhességi fogászati szűrés } \\
\text { során kapott-e információt } \\
\text { saját szájegészségével } \\
\text { kapcsolatban?* }\end{array}$ & Igen, nem \\
\hline & $\begin{array}{l}\text { Ha az előző válasz „igen”, } \\
\text { mit?* }\end{array}$ & (Szöveges válasz) \\
\hline & $\begin{array}{l}\text { Fontosnak tartja-e a } \\
\text { fogápolást tejfogazatban? }\end{array}$ & Igen, nem \\
\hline \multirow[t]{2}{*}{ Végzettség } & Anya & $\begin{array}{l}\text { Alapfokú, középfokú, } \\
\text { felsőfokú }\end{array}$ \\
\hline & Apa & $\begin{array}{l}\text { Alapfokú, középfokú, } \\
\text { felsőfokú }\end{array}$ \\
\hline
\end{tabular}

- A gyermek napi rendszeres folyadékbevitele.

- Miből történik a gyermek itatása?

- Kapott-e a szülő egészségügyi szakembertől bármilyen információt a gyermeke szájegészségével kapcsolatosan, ha igen, mit?

- Várandóssága során kapott-e az édesanya egészségügyi szakembertôl bármilyen információt saját szájegészségével kapcsolatosan, ha igen, mit?

A gyermekek fogászati statusa és a szüloók válaszai közötti összefüggéseket kiértékeltük. Mann-Whitney-próbával vizsgáltuk, hogy van-e különbség a gyermekek szuvas fogainak száma között a fogászati prevenciós tájékoztatásban részesült és a nem tájékoztatott szülők esetében. A tájékoztatottság függvényében khi-négyzetpróbával értékeltük, hogy van-e különbség a gyermekek által rendszeresen fogyasztott folyadék cukortartalmát illetően. Az alapján, hogy miből történik a gyermek itatása, két kategóriára osztottuk a vizsgált csoportot: egy fogászati szempontból előnyösebb, cumisüveget nem alkalmazó csoportra és egy cumisüveget is használó csoportra. Khi-négyzet-próbát alkalmaztunk a statisztikai vizsgálathoz. Szintén khi-négyzet-próbával vizsgáltuk, hogy az első 6 hónapban történő táplálás módja hatással van-e a hozzátáplálás időszakában és a későbbiekben választott folyadékbeviteli módra. A szülők legmagasabb iskolai végzettsége és a cariesfrekvencia közötti kapcsolat vizsgálatára Kruskal-Wallis-tesztet alkalmaztunk. A statisztikai analízist az SPSS Statistics program 24-es verziójával (BM Corporation, Armonk, NY, Amerikai Egyesült Államok) végeztük. Az eredményt statisztikailag szignifikánsnak tekintettük $\mathrm{p}<0,05$ esetén.

\section{Eredmények}

\section{A szürôpizsgálat eredménye}

A 6045 vizsgált fogból 248 (4,01\%) esetében igazolódott caries. A vizsgált csoport cariesfrekvenciája 15,46\% volt, 56 gyermek (25 lány, 31 fiú) rendelkezett szuvas foggal. A populáció df-t-index-értéke $0,685 \pm 2,20$ volt. Egy gyermek esetén a df-t-index elérte a 20 -at, a maximális értéket, vagyis a gyermek teljes előtört tejfogazatának minden foga carieses volt. A ${ }^{\mathrm{m}} \mathrm{df}$-index értéke 0,758 $\pm 2,42$ volt annak köszönhetően, hogy a gyermekek csak $58,9 \%$-a (214 eset) rendelkezett teljes előtört tejfogazattal a szúrés idején. Az átlagosan előtört fogak száma 18,06 volt. A SiC-index értéke $2,06 \pm 3,33$ volt. Caries $33 \%$-ban csak a felső metszőfogakra, 22\%-ban csak az alsó és felső tejmolarisokra lokalizálódott. Együttesen előforduló front- és rágófog-érintettség $45 \%$-ban volt detektálható (3. ábra). A S-ECC 6\%-ban olyan súlyos mértéket ért el, hogy az alsó frontfogak is cariesesek voltak (S-ECC III.). A vizsgált populációban nem találtunk kezelt, azaz tömött vagy fogszuvasodás miatt eltávolított fogat $(\mathrm{CI}=0 \%)$, a gyermekek def-indexének $100 \%$-át a „d" összetevő adja.

\section{A kérdöin eredménye}

A válaszadók minden esetben hangsúlyozták a fogmosás fontosságát, így a későbbi statisztikai kiértékelésben az

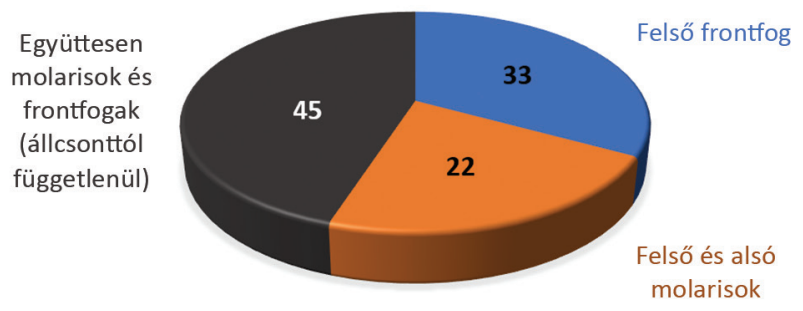

3. ábra $\quad$ A korai gyermekkori fogszuvasodás előfordulása az érintett tejfogtípusok szerint bölcsődés korú populációban (\%)

erre a kérdésre adott válaszokat nem vettük figyelembe. Tájékoztatásban 150 szülő (49\%) részesült. 68 esetben $(45,3 \%)$ szájhigiénés instrukciókat kaptak a szülők, 16 szülő $(10,6 \%)$ kapott mind táplálkozási, mind szájhigiénés információt, 5 esetben $(3,3 \%)$ kizárólag a fogászati szû́rés fontosságára hívták fel a figyelmet. A válaszadók 65 esetben $(43 \%)$ nem éltek a szöveges válaszlehetőség- 
gel. Az alacsony esetszámok miatt a kérdóív ezen eredményei statisztikailag érdemben nem voltak összevethetôk a cariologiai statusszal.

Nem volt szignifikáns különbség $(\mathrm{p}=0,196)$ a gyermekek szuvas fogainak számát illetően a fogászati prevenciós tájékoztatásban részesült és a nem tájékoztatott szülők esetében.

A tájékoztatottságot és a gyermekek által rendszeresen fogyasztott folyadék cukortartalmát illetően megállapítható, hogy a tájékoztatásban részesülteknek csak a 19,5\%-a itatja gyermekét vízzel, ugyanez az arány a nem tájékoztatottak esetében 29,5\%. A fogászati szempontból előnyösebb/kedvezőtlenebb itatási szokásokat öszszehasonlítva statisztikailag nem mutatható ki szignifikáns különbség a tájékoztatottság függvényében ( $\mathrm{p}=$ 0,453) (4. ábra). Az italfogyasztás módját és a caries gyakoriságát vizsgálva, a cumisüveget használó gyermekek esetén a caries előfordulása gyakoribb volt a cumisüveget nem használókkal szemben. Szignifikáns különbség nem igazolható, de tendencia kimutatható $(\mathrm{p}=$ 0,069). Az első 6 hónapban kizárólag anyatejjel táplált gyermekek szüleinek csak a 31,9\%-a választotta a cumisüvegből történő táplálást, míg a tápszerrel táplált gyermekek szülei 71,2\%-ban, a tápszerrel és anyatejjel táplált gyermekek szülei 61,9\%-ban cumisüveget is alkalmaztak $(\mathrm{p}<0,001)$.

A folyadék minőségét tekintve az anyatejjel táplált gyermekek 75\%-ánál a víz a rendszeresen fogyasztott folyadék, míg a tápszerrel táplált gyermekeknél ez az arány csak $52 \%$.

Felmértük a vizsgált populációban a szülők legmagasabb iskolai végzettségét. Anyák esetén a felsőfokú végzettség volt a leggyakoribb (57,9\%, alapfokú: 5,3\%, középfokú: 36,8\%), míg apák esetén a középfokú végzettség volt a legmagasabb arányú $(49,5 \%$, alapfokú: $5,4 \%$, felsőfokú: $45,1 \%$ ). A legmagasabb iskolai végzettség és a cariesfrekvencia kapcsolatát mindkét szülőre megvizsgáltuk. Az anya iskolai végzettsége szignifikáns összefüggést mutatott a caries előfordulásával. Minél magasabb az anya iskolai végzettsége, annál kevesebb szuvas foggal rendelkeznek a gyermekek $(\mathrm{p}=0,015)$. Az alapfokú iskolázottságú szülők gyermekei 25\%-ban ( 16 gyermekből 4) rendelkeztek carieses fogazattal, középfokú végzettség esetén 18,9\%-nál (128-ból 28 gyermek) találtunk szuvas laesiót, míg felsőfokú végzettségü szülők gyermekeinél 11,8\%-ban (135-ből 16) volt jelen caries (különbség a felsőfokú és a középfokú végzettség között: $\mathrm{p}=$ 0,470; a felsőfokú és az alapfokú között: $\mathrm{p}=0,004$; a középfokú és az alapfokú között: $\mathrm{p}=0,012 ; 5$ ábra $)$. Az alapfokú végzettségű édesanyák gyermekei 2,94 \pm 1,13 szuvas foggal rendelkeztek, a középfokú végzettségüeknél ugyanez az érték $0,87 \pm 0,28$, felsőfokú végzettség esetén $0,34 \pm 0,76$ volt. Az apák iskolai végzettsége és gyermekeik cariesfrekvenciája között tendencia volt kimutatható ( $\mathrm{p}=0,088)$. A felsőfokú végzettséggel rendelkező anyáknál a legmagasabb a pohárral történő itatás aránya, az iskolai végzettség csökkenésével csökken ez az

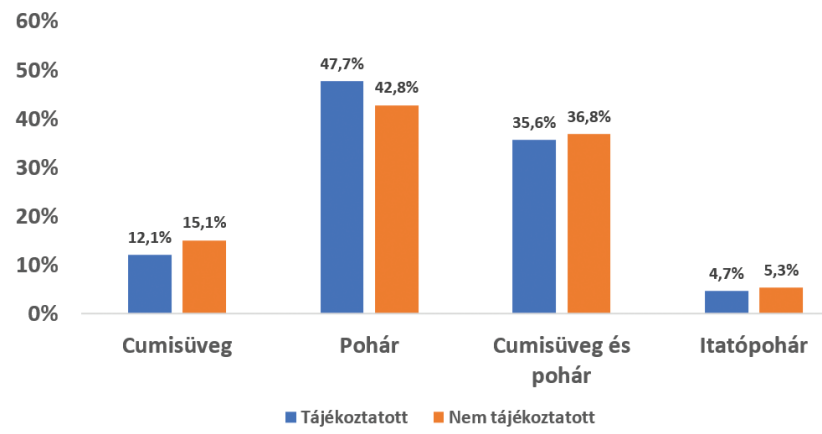

4. ábra | A folyadékfogyasztás módja a tájékoztatás függvényében

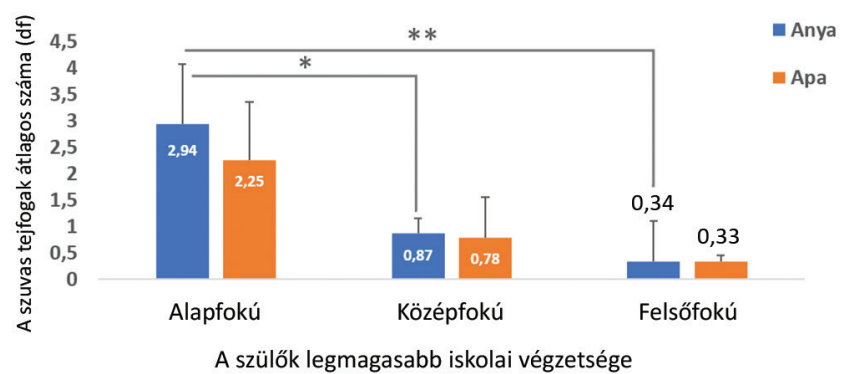

5. ábra

A szuvas tejfogak előfordulása bölcsődéskorúak körében a szülői iskolázottsággal összefüggésben (átlag $\pm \mathrm{SD} ; \quad{ }^{*} \mathrm{p}<0,05$; $\left.{ }^{* *} \mathrm{p}<0,01\right)$

$\mathrm{SD}=$ standard deviáció

arány (felsőfokú végzettség: 66,7\%, középfokú: 41,3\%, alapfokú: 31,3\%; p = 0,009). Apák esetén ez az összefüggés nem mutatható ki $(\mathrm{p}=0,199)$. Szignifikáns összefüggés mutatható ki a szülők legmagasabb iskolai végzettsége és a fogyasztásra kínált folyadék típusa között. Az iskolai végzettség növekedése a vízfogyasztás arányának növekedésével, illetve a cukros folyadék arányának csökkenésével jár mind az anya $(\mathrm{p}=0,028)$, mind az apa $(\mathrm{p}=0,05)$ esetében. A felsőfokú végzettséget szerzett anyák táplálják a legnagyobb arányban gyermekeiket anyatejjel (felsőfokú végzettség: 53,4\%, középfokú: $34,2 \%$, alapfokú: $37,5 \% ; p=0,006$ ). Egyéb szociológiai, szocioökonómiai szempontokra vizsgálatunk nem terjedt ki.

\section{Megbeszélés}

Tanulmányunk céljaként tűztük ki, hogy rávilágítsunk a hazánkban jelenleg múködő gyermekfogászati szűrőrendszer átalakításának szükségességére, amely lehetőséget biztosíthat korai prevenciós konzultációra, illetve a magas caries-rizikócsoportba tartozó gyermekek mielőbbi felderítésére és gondozására.

Magyarországon még nem közöltek a 36 hónaposnál fiatalabb gyermekek körében végzett fogászati szűrővizsgálati eredményeket. Az utolsó fellelhető epidemiológiai adat 2008-ból származik, melyben a 12 évesek körében 
a maradó fogakra vonatkozó DMF-T-index 2,4 volt [16], míg a 6 évesek def-indexe 3,3. Vizsgálatunkban felmértük a pécsi bölcsődés korosztály fogazati statusát, mivel a már említett okok miatt ez a pácienspopuláció a fogorvosi ellátórendszer számára kevésbé érhető el. Az általunk vizsgált 362 gyermek 15,46\%-a ECC-érintett. A WHO 2020-ra megfogalmazott célja, hogy a 6 éves gyermekek $80 \%$-a egészséges fogazattal rendelkezzen, a carieses gyermekek aránya 20\% alá csökkenjen [17]. Eredményeink alapján látható, hogy a vizsgált populációban már 3 éves kor alatt a gyermekek 15,46\%-a rendelkezik szuvas foggal, és ez 6 éves korra feltehetően tovább romlik. A vizsgált populáció df-indexe 0,685 , melyet súlyosbít, hogy a gyermekek egy része még nem rendelkezik teljes tejfogazattal. Mivel a „d” komponens adja a def-index 100\%-át (kezelt fogat nem találtunk), a cariesszel érintett gyermekek mindegyikénél fogászati ellátás lenne indokolt. Az ellátási szülkséglet egyénenként változóan a professzionális preventív ellátástól a fog restaurálásáig, esetenként extrakciójáig terjed. Az általunk javasolt, az előtört fogak számával korrigált ${ }^{\mathrm{m}} \mathrm{df}$-index jobban tükrözi a valós helyzetet. Ez alapján a vizsgált csoport minden gyermeke átlagosan 0,758 szuvas tejfoggal rendelkezik. SiC-indexszel kalkulálva látható, hogy a vizsgált populáció cariologiailag legérintettebb egyharmadát értékelve a gyermekek átlagosan több mint $2(2,01626)$ carieses foggal rendelkeznek.

Az angolszász szakirodalom a kezeletlen fogszuvasodás talaján kialakuló fogfájdalmat „dental neglect”-ként definiálja [18]. Ez felvetheti a gondozási kötelezettség elmulasztásának, így kiskorú veszélyeztetésének gyanúját. A fogászati negligencia rövid (rekurráló infekciók) és hosszú távú (fogvesztés, a beszédfejlődés zavara, táplálkozási nehezítettség, esztétikai hátrányok, „bullying”, végső soron alacsonyabb iskolai teljesítőképesség és életminőség) következményei szintén jól definiáltak [19]. Előfordul, hogy fogorvoskollégáink is erősítik azt a tévhitet, miszerint a szuvas tejfogak kezelése szükségtelen. $\mathrm{Ez}$ is oka lehet annak, hogy a gyermekek sok esetben olyan stádiumban jutnak ellátásra, amikor az egyetlen terápiás lehetőség a tejfog eltávolítása. A korai, a maradó fog várható előtörési ideje előtt fél évvel történő tejfogextrakciónak hosszú távú következményei lehetnek. Előfordulhat a gyermek fizikai fejlődésének lassulása a táplálkozási nehezítettség miatt [4], illetve a fogívben kialakuló helyhiány, a maradó fogak előtörési nehezítettsége, impakciója is [20]. Az ECC gyors progressziójú megbetegedés. A kezeletlen caries gyorsan elérheti a pulpát, erős fájdalommal járhat, amely étkezési, alvási nehezítettséget okozhat. Talaján súlyos következményes betegségek - például periostitis - is kialakulhatnak [21], amelyek esetén akár hospitalizáció is szükségessé válhat. Előfordulhat a gyermekek életkorából adódóan a szükséges fogászati beavatkozások korrekt elvégzése többnyire csak általános anesztéziában kivitelezhető, egynapos sebészeti ellátás keretein belül. Egy 2018. évi ausztrál tanulmány szerint a megelőzhető kórházi osztályos felvé- telek 9\%-ának oka fogászati eredetü; az első helyen a fogszuvasodás, a második helyen pedig az impakció áll [22], amely korai tejfogextrakció következménye is lehet [20]. Magyarországi szakirodalmi adat nem áll rendelkezésre, de könnyen belátható, hogy egy gyermek megelőzhető betegség miatti hospitalizációja társadalombiztosítási és nemzetgazdasági kérdéseket is felvet, hiszen a kezelés költsége, illetve a szülők munkából történő kiesése hatékony prevenciós intézkedésekkel jelentősen csökkenthető lenne. 2019-ben a Pécsi Tudományegyetem Klinikai Központja Fogászati és Szájsebészeti Klinikáján fogászati okból altatott 367 páciensünk 16,19\%-a (62 eset) 3 éves vagy fiatalabb egészséges kisgyermek volt.

Eredményeinkből látható, hogy a vizsgált, 3 év alatti populáció CI-je 0\%, azaz a gyermekek nem rendelkeznek caries miatt kezelt (tömött, eltávolított) fogakkal. 2014ben az 5 évesek körében a CI 14\% volt az Egyesült Királyságban, 13\% Skóciában [23].

Klinikai tapasztalataink szerint, melyeket a szakirodalom is alátámaszt, a szülők a szájhigiénés szokások korai elsajátítását, a helyes diétás alapelvek betartását a tejfogazati korban alulértékelik $[24,25]$. A szájhigiénés kérdésekre adott válaszok azt mutatják, hogy a szülők rendszerint helyes információkkal rendelkeznek, válaszaik azonban nem feltétlenül a kisgyermek életében kialakított szájápolási szokásokat, mint inkább egy késóbbi életszakaszban bevezetni kívánt rendszert tükröznek.

Eredményeinkből látható, hogy a tájékoztatott és a nem tájékoztatott csoport gyermekeinek cariesfrekvenciája szinte azonos. Továbbá a tájékoztatásban részesültek nagyobb százalékban adnak cariogen innivalót gyermekeiknek, mint a tájékoztatásban nem részesültek. Ez arra enged következtetni, hogy a tájékoztatás minősége vagy gyakorisága nem elegendő a megfelelő ismeretek elsajátítására. Felvetődik egy fogászati prevenciós irányelv kidolgozásának szükségessége, amely pontosan meghatározná, milyen információkkal kell, hogy rendelkezzenek a gyermekük szájegészségéért teljes mértékben felelős szülők. A fogászati szakember által végzett prevenciós tájékoztatásnak a megelőzés minden lehetőségéről - úgymint megfelelő szájhigiéné, táplálkozás, a korai szűrővizsgálat és kezelés jelentősége és típusai - teljes körű információval kell szolgálnia. Ez messze túlmutat a fogszuvasodásnak a köztudatban elterjedt vagy akár az egészségügyi fórumokon kommunikált megelőzési módszerein. Az egyszeri tájékoztatás nem elegendő. Hosszú távon az egészségtudatosság fenntartása, a motiváció csak rendszeres, lehetőség szerint több forrásból (gyermekorvos, védőnő, fogorvos) és egységes szakmai elvek alapján történő effektív kommunikációval őrizhető meg [26]. Tanulmányok alátámasztják, hogy az ECCprevenciót a várandósság idején érdemes megkezdeni, hiszen az anya szájegészsége és a gyermek szájhigiénés szokásainak kialakítása kiemelkedő jelentőséggel bír a betegség megelőzésében [27]. 
Hangsúlyoznunk kell, hogy az első 6 hónapban kizárólagosan szoptatott csecsemók hosszú távon is profitálnak, hiszen szüleik (elsősorban édesanyjuk) nagyobb eséllyel választják a pohárból, vízzel történő folyadékfogyasztás módját. Fontos azonban kiemelni, hogy a hoszszú távon szoptató anyák egy része nincs tisztában azzal a ténnyel, hogy az anyatej is cariogen. Tham és mtsai (2015) összefoglaló közleményükben leírták, hogy a 12 hónapos koron túl szoptatott kisgyermekek cariesrizikója magasabb, mint az egy évnél rövidebb ideig szoptatott csecsemók esetében. Ezenfelül külön rizikócsoportot képeznek a 12 hónapon túl gyakran, éjszaka is szoptatott gyermekek [28]. A WHO jelenleg kizárólagos szoptatást ajánl az élet első 6 hónapjában, majd ezt követően a hozzátáplálás mellett a gyermek igénye szerinti szoptatás folytatását 2 éves korig vagy akár azon túlmenően [29].

Szatko és mtsai (2004) tanulmánya szerint az anya iskolai végzettsége közvetlenül korrelál a szájhigiénés ismereteivel [30]. Ezt az összefüggést tükrözik vizsgálatunk eredményei is. A felsőfokú végzettségú anyák gyermekeinél volt a legalacsonyabb a cariesfrekvencia és a legmagasabb arányú a pohárból történő vízitatás. Az alapfokú végzettségü anyák esetén - bár kis esetszám mellett (összesen 16 gyermek, a teljes minta 5,2\%-a) jelentősen magasabb volt a caries frekvenciája és a pohárból történő vízitatás. Az utóbbi csoport kis esetszámára magyarázatot adhat, hogy a vizsgálatot bölcsődés korú gyermekeknél végeztük, és a magasabb iskolai végzettséggel rendelkezők feltehetően előbb visszatérnek a munka világába.

Összegzésképpen kiemelendő a fogászati prevenció fontosságának hangsúlyozása már csecsemőkortól kezdve. Ehhez szükségesnek tartjuk egy fogászati szakemberek által kidolgozott prevenciós irányelv megfogalmazását, meghonosítását és egészségügyi szakemberek által több forrásból történő kommunikációját már a várandósság időszakában. Javasoljuk az Amerikai Gyermekfogorvosok Társasága által ajánlott első fogászati szúrővizsgálat bevezetését 6 és 12 hónapos kor között, a páciens caries-rizikócsoportba történő besorolását és a rizikócsoportnak megfelelő időközönként történő szürővizsgálatát. Az International Association of Paediatric Dentistry (IAPD) fontosnak tartja felhívni a figyelmet az ECC jelentőségére a szülők és az egészségügyi ellátószemélyzet körében. A védőnők és a gyermekháziorvosok kötelező továbbképzésének része kell, hogy legyen a fogászati prevenciós irányelveknek és egy alapfokú diagnosztikai készségnek az elsajátítása. Csak hatékony prevenciós hálózat kiépítésével csökkenthető a kisgyermekkori fogszuvasodás gyakorisága Magyarországon. Eredményként azt várjuk, hogy a szájegészség már kisgyermekkortól kezdve az egészségtudatos életmód részévé válik, s ettől hosszú távon a caries epidemiológiai mutatók javulását reméljük.

\section{A vizsgálat korlátai}

A szűrővizsgálat elvégzését visszautasító szülők számáról nincs pontos információnk. Tapasztalataink és a gondozók visszajelzése alapján a visszautasítók száma elenyésző volt. A szülők általánosságban szívesen fogadták a fogászati szürésben való részvételt. Vizsgálatunkban az alapbetegséggel rendelkező gyermekek nem kerültek kizárásra, mivel azonban a prevenciós és ellátási igény ezen gyermekek esetében fokozottan jelentkezik, véleményünk szerint a vizsgálat célkitüzését, az eredményeket ez a limitáció nem befolyásolja.

Anyagi támogatás: A közlemény megírása, illetve a kapcsolódó kutatómunka anyagi támogatásban nem részesült.

Szerzői munkamegosztás: R. A.: Adatgyüjtés, a cikk megírása. D. T.: Statisztikai értékelés. Cs. L., S. N., K. K.: Adatgyüjtés. B. Sz. I.: Szakmai tanácsadás. S. B.: A hipotézis kidolgozása, koordinálás, szakmai véleményezés. A cikk végleges változatát valamennyi szerző elolvasta és jóváhagyta.

Érdekeltségek: A szerzőknek nincsenek érdekeltségeik.

\section{Köszönetnyilvánítás}

A szerzők hálás köszönetüket fejezik ki $d r$. Rózsa Fanninak a kutatási módszer és a szülőii kérdőív kidolgozásában nyújtott támogatásáért.

\section{Irodalom}

[1] Meyer F, Enax J. Early childhood caries: epidemiology, aetiology, and prevention. Int J Dent. 2018; 2018: 1415873.

[2] Early Childhood Caries: IAPD Bangkok declaration. Int J Paediatr Dent. 2019; 29: 384-386.

[3] Colak H, Dülgergil CT, Dalli M, et al. Early childhood caries update: a review of causes, diagnoses, and treatments. J Nat Sci Biol Med. 2013; 4: 29-38.

[4] Anil S, Anand PS. Early childhood caries: prevalence, risk factors, and prevention. Front Pediatr. 2017; 5: 157.

[5] De Grauwe A, Aps JK, Martens LC. Early childhood caries (ECC): what's in a name? Eur J Paediatr Dent. 2004; 5: 62-70.

[6] Selwitz RH, Ismail AI, Pitts NB. Dental caries. Lancet 2007; 369: 51-59.

[7] Hooley M, Skouteris H, Boganin C, et al. Parental influence and the development of dental caries in children aged 0-6 years: a systematic review of the literature. J Dent. 2012; 40: 873-885

[8] American Academy of Pediatric Dentistry. Periodicity of examination, preventive dental services, anticipatory guidance/counseling, and oral treatment for infants, children, and adolescents. Pediatr Dent. 2017; 39: 188-196.

[9] Oubenyahya H, Bouhabba N. General anesthesia in the management of early childhood caries: an overview. J Dent Anesth Pain Med. 2019; 19: 313-322.

[10] Szmirnova I, Gellérd E, Pintér GT, et al. Dental and oral surgical treatment of the mentally retarded in Hungary: the situation in the past, currently and hopes for the future. [A szellemi fogya- 
tékosok fogászati-szájsebészeti ellátásának múltja, jelene és remélt jövője Magyarországon.] Orv Hetil. 2019; 160: 1380-1386. [Hungarian]

[11] Paglia L, Scaglioni S, Torchia V, et al. Familial and dietary risk factors in early childhood caries. Eur J Paediatr Dent. 2016; 17: 93-99.

[12] Martignon S, Pitts NB, Goffin G, et al. Caries care practice guide: consensus on evidence into practice. Br Dent J. 2019; 227: 353-362. [Erratum: Br Dent J. 2019; 227: 988.]

[13] Pitts NB, Ekstrand KR The ICDAS Foundation. International Caries Detection and Assessment System (ICDAS) and its International Caries Classification and Management System (ICCMS) - Methods for staging of the caries process and enabling dentists to manage caries. Community Dent Oral Epidemiol. 2013; 41: e41-e52.

[14] Bratthall D. Introducing the Significant Caries Index together with a proposal for a new global oral health goal for 12 -year-olds. Int Dent J. 2000; 50: 378-384.

[15] Walsh J. International patterns of oral health care - the example of New Zealand. N Z Dent J. 1970; 66: 143-152.

[16] Hysi D, Eaton KA, Tsakos G, et al. Proceedings of workshop, held in Constanta, Romania on 22 May 2014, on Oral Health of Children in the Central and Eastern European countries in the context of the current economic crisis. BMC Oral Health 2016; 16(Suppl 1): 69.

[17] Petersen PE. Changing oral health profiles of children in Central and Eastern Europe - challenges for the 21 st century. IC Digest 2003; 2 : 12-13

[18] Bradbury-Jones C, Innes N, Evans D, et al. Dental neglect as a marker of broader neglect: a qualitative investigation of public health nurses' assessments of oral health in preschool children. BMC Public Health 2013; 13: 370.

[19] Hartung B, Schaper J, Fischer K, et al. Care for children with dental neglect: identification of problems and approaches to solving them. Int J Legal Med. 2019; 133: 641-650.

[20] Law CS. Management of premature primary tooth loss in the child patient. J Calif Dent Assoc. 2013; 41: 612-618.
[21] Mensch K, Nagy G, Nagy Á, et al. Characteristics, diagnosis and treatment of the most common bacterial diseases of the oral cavity. [A szájüreg leggyakoribb bakteriális eredetű kórképeinek jellegzetességei, diagnosztikája és kezelése.] Orv Hetil. 2019; 160: 739-746. [Hungarian]

[22] Acharya A, Khan S, Hoang H, et al. Dental conditions associated with preventable hospital admissions in Australia: a systematic literature review. BMC Health Serv Res. 2018; 18: 921.

[23] Innes N, Evans D. Managing caries in primary teeth. BDJ Team 2015; 1: 14118. [Published 28 November 2014]

[24] Curzon M, Pollard M. Do we still care about children's teeth? Br Dent J. 1997; 182: 242-244.

[25] Vittoba Setty J, Srinivasan I. Knowledge and awareness of primary teeth and their importance among parents in Bengaluru City, India. Int J Clin Pediatr Dent. 2016; 9: 56-61.

[26] Wendt LK, Carlsson E, Hallosten AL, et al. Early dental caries risk assessment and prevention in pre-school children: evaluation of a new strategy for dental care in a field study. Acta Odontol Scand. 2001; 59: 261-266.

[27] Xiao J, Alkhers N, Kopycka-Kedzierawski DT, et al. Prenatal oral health care and early childhood caries prevention: a systematic review and meta-analysis. Caries Res. 2019; 53: 411-421.

[28] Tham R, Bowatte G, Dharmage SC, et al. Breastfeeding and the risk of dental caries: a systematic review and meta-analysis. Acta Paediatr. 2015; 104: 62-84.

[29] Moynihan P, Tanner LM, Holmes RD, et al. Systematic review of evidence pertaining to factors that modify risk of early childhood caries. JDR Clin Trans Res. 2019; 4: 202-216.

[30] Szatko F, Wierzbicka M, Dybizbanska E, et al. Oral health of Polish three-year-olds and mothers' oral health-related knowledge. Community Dent Health 2004; 21: 175-180.

(Radácsi Andrea dr., Pécs, Dischka Győző u. 5., 7621 e-mail: radacsi.andrea@pte.hu)

\section{"Damnare est obiurgare cum auxilio est opus." (Ha segítség kell, a feddés nem helyénvaló.)}

A cikk a Creative Commons Attribution 4.0 International License (https://creativecommons.org/licenses/by/4.0/) feltételei szerint publikált Open Access közlemény, melynek szellemében a cikk bármilyen médiumban szabadon felhasználható, megosztható és újraközölhetö, feltéve, hogy az eredeti szerző és a közlés helye, illetve a CC License linkje és az esetlegesen végrehajtott módositások feltüntetésre kerülnek. (SID_1) 